\title{
LATVIA STUDENTS' INTEREST IN DIFFERENT SCIENCE SUBJECT TOPICS
}

\author{
Juris Porozovs \\ University of Latvia, Latvia
}

\begin{abstract}
Students' interest in science subjects is insufficient in different countries. One of the main reasons of decreased students' interest in science subjects is that often science subjects in schools are taught in a traditional way, separated from real life, and it is difficult for students to relate their knowledge to their personal interests. The aim of the study was to clear out Latvia students' interest in different science subjects and science subject topics. The electronic survey of Latvia students from different specialities was carried out. $12^{\text {th }}$-grade secondary school students from two Riga schools, University of Latvia 1st course pedagogical specialities students, University of Latvia Riga Medical College $1^{\text {st }}$ course doctors' assistant program students and Latvian Academy of Music $1^{\text {st-course students }}$ were surveyed. Altogether 235 students were questioned. The results of the research showed that the interest of Latvia students from different specialities in physics and chemistry is rather low: many students have average interest in topics of these subjects. The lowest interest in physics and chemistry from surveyed student groups have Latvian Academy of Music students. The most interesting physics topic for all student groups is the structure of the Universe. From chemistry subject topics secondary school students are more interested in types of chemical reactions and electrolytic dissociation theory and carbohydrates, fats and oils. The majority of the University of Latvia pedagogical specialities students are not interested in different topics of chemistry. Most of all Latvia students are interested in biology. University of Latvia Riga Medical College doctors' assistant program students are most of all interested in biology from surveyed student groups. The most interesting topics of biology for all student groups are genetics and gene engineering, the human organism, human health, origin and evolution of life and ecology. The majority of students have average interest in such topics as construction and diversity of plants. An important task of teachers is to find out a way, how to raise students' interest in science subjects. Teachers should use a student-centred approach and interactive methods for teaching science subjects in order to achieve the personal interest of students in acquiring science subjects.
\end{abstract}

Keywords: students, science subjects, interest, physics, chemistry, biology. 


\section{Introduction}

One of the most important factors influencing the growth of public well-being is students' science literacy. Students' science literacy has the essential role in the development of modern science and technologies driven economy (Cedere et al., 2015). Nevertheless, investigations reveal the contradiction between the increasing social needs and the insufficient level of young peoples' education in sciences (Birzina \& Cedere, 2017). Studies have shown that different countries students have insufficient interest in science subjects (Cedere et al., 2014, Cedere et al., 2018). One of the main reasons of decreased interest of different countries students in science subjects is that often science subjects in schools are taught in a traditional way, separated from real life, and it is difficult for students to relate their knowledge to their personal interests (Cedere et al., 2015). There are many factors affecting the motivation of pupils towards science subjects in modern educational practice. External factors could form the positive attitude of pupils, such as cooperative projects of pupils, teachers and scientists, joint programs and dissemination of research activities. Some internal factors related with educational practice and constructive learning paradigm (integrated teaching and structured-coordinated research) are important as well (Pečiuliauskienè, 2012).

Decreasing interest in Science among students calls for the need to revise the contents of the curricula for Science subjects, including Biology. Modern Biology curricula should not only contain key biological concepts but also provide a teacher with sufficient space to develop students' competencies of scientific work and positive attitudes to Science. When preparing the curriculum, it is necessary to consider also students' interest in selected curriculum topics and their benefit for everyday life. The research confirmed the positive interest in Biology among the majority of students who prefer direct, active participation in the process of knowledge acquisition through the study and exploration of living organisms as well as by the execution and assessment of practical works and experiment (Čipkova et al., 2018). The students' attitudes and self-efficacy beliefs in science subjects should be taken into account in secondary school biology education, because gender stereotypes and low self-efficacy beliefs may affect students' future career plans (Uitto, 2014). Several avenues are open to students who wish to study advanced science or mathematics in high school, which include Advanced Placement courses and teacher-designed courses unaffiliated with organized programs (Sadler et al., 2014).

The successful way to gauge and foster students' interest in science subjects is to understand the ways in which students express curiosity about the nature of an object, phenomena, or a given topic (Luce \& Hsi, 2015). 
The teacher's personality and professional mastery have great importance on promoting students' cognitive interest. Interactive teaching/learning methods developing analytical thinking and practical skills promote the acquisition of the science subjects (Cedere et al., 2016). Studies have shown that integration into classroom the science education of short presentations of cutting-edge science and emerging technologies has positive impact on students' learning outcomes (Michael et al., 2017). Career-related instructions implemented in secondary school science education is a way how to rise students' interest in subject and to promote students' science career awareness (Salonen et al., 2018).

Teachers and professors of life science subjects have come to the conclusion that many college students have difficulties in studying science subjects (mathematics, physics, chemistry), and they see the main reasons of these difficulties in shaky background of students arriving at the college level and difficulties in seeing the purpose of studying these subjects (Taly et al., 2019). So it is necessary clearly demonstrate the importance of studying these subjects and show them how concepts that might seem at first very abstract have a high practical use in biology. Previous experiences have taught that traditional lectures do not constitute an appropriate and efficient solution to these issues, even when a lot of care is put into showing examples and applications from biology. The teachers found that effective way how to rise students' interest about science subjects is the one-week workshop. The workshop adopts a large variety of teaching methods including group activities, practical activities and online games and demonstrations. The goal of the workshops was to boost students' interest and motivation by showing them through unconventional teaching how all subjects matter and how the knowledge from very different disciplines is needed to be able to tackle interesting and fundamental biological questions. For example, professors developed a workshop based on the theme of the interaction of biomolecules with drugs. Students were asked to investigate how caffeine and nicotine work at the molecular level. Taking a wider perspective this concept and methods can be easily exported for the other scientific disciplines. The main key to developing similar workshops is to find the appropriate subject in which students are interested and to use appropriate pedagogical methods (Taly et al., 2019).

The important question is how the composition of the courses affects the domain-specificity of these constructs. Using data from a large-scale study in Germany, scientists compared ninth-grade students who were taught science as an integrated subject with students who were taught biology, chemistry, and physics separately with regard to the dimensional structure of their self-concepts and interests (Jansen et al., 2019). Whereas the structure of the constructs was six-dimensional in both groups (self-concept and 
interest factors for biology, chemistry, and physics), the correlations between the domain-specific factors were higher in the integrated group. The pattern of gender differences differed across groups. Whereas male students generally showed higher self-concept and interest in physics and chemistry, a small advantage for male students in biology was only present in integrated science teaching group. The conclusion is that aspects of the learning environment such as course composition may affect the dimensional structure of motivational constructs (Jansen et al., 2019).

Successful studies of young people in science-related professions and interest in these fields are closely correlated with the experience and interest in science subjects acquired during primary school. Research has shown that attending a high school with a science, technology, engineering, and/ or mathematics (STEM) program has a positive association with students' STEM-related outcomes (Bottia et al., 2017). Studies have shown, that access to internet with appropriate speed, different databases, equipping the research labs for scientific research and providing the advanced laboratory devices, financial support of university research unit and encouraging the students in different ways, can strengthen the participation of students in conducting research activities and promote their scientific career (Safari et al., 2015).

\section{Aim of the Study}

The main goal of this research is to identify Latvia students' interests in science subjects. An important task of teachers and educators is to rise students' interest in science subjects. In order to rise this interest, it is necessary to find factors that influence students' motivation to learn, methods which are most appropriate for rising students' interest in science subjects and to know in which topics of science subjects different students are more interested. The aim of the study was to clear out different groups of Latvia students' interest in science subjects and science subject topics.

\section{Materials and Methods}

The electronic survey of Latvia students from different specialties was carried out. $12^{\text {th }}$ grade secondary school students from two Riga schools, the University of Latvia $1^{\text {st }}$ course pedagogical specialties students, the University of Latvia Riga Medical College $1^{\text {st }}$ course doctors' assistant program students and Latvian Academy of Music $1^{\text {st }}$ course students were surveyed. Altogether 235 students were questioned (96 secondary school students; 73 the University of Latvia pedagogical specialties students; 34 the University of Latvia Riga Medical College doctors' assistant program 
students and 32 Latvian Academy of Music students). The survey was worked out in order to clarify Latvia students' interest in different science subjects and different science subject topics.

\section{Results}

Results of the survey about students' interest in different science subjects are displayed in Figure 1 till Figure 3. Results of the research showed that the majority of students have average interest in physics (see Fig. 1). Only $11 \%$ of secondary school students are very interested and $16 \%$ of them are interested in physics. University of Latvia students are less interested in physics in comparison with secondary school students. Only 7\% of the University of Latvia pedagogical specialties students and the University of Latvia Riga Medical College doctors' assistant program students are very interested in physics, but $12 \%$ of pedagogical specialties students and $16 \%$ of doctors' assistant program students are interested in physics.

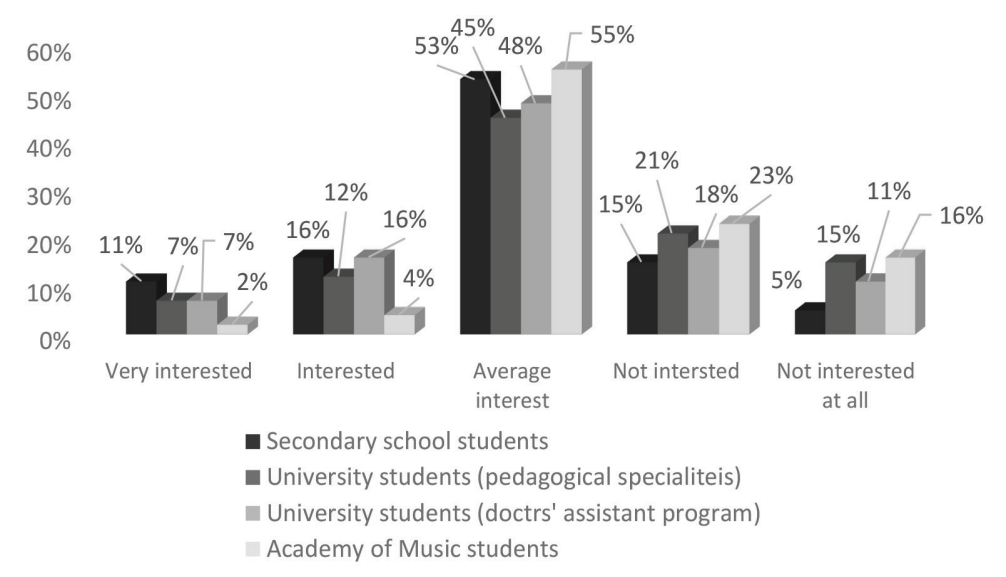

Figure 1. The interest of Latvia students from different specialties in physics (in $\%$ from the number of respondents in groups)

Less of all interested in physics from different student groups are Latvian Academy of Music students: 23\% of Latvian Academy of Music students are not interested in physics and 16\% of Latvian Academy of Music students are not interested in physics at all. Many pedagogical specialties students also are not interested in physics: $21 \%$ of pedagogical specialties students are not interested in physics and $15 \%$ are not interested in physics at all.

Latvia students' interest in chemistry is not high as well (see Fig. 2). 9\% of secondary school students are very interested in chemistry and $16 \%$ of them are interested in chemistry but the majority of secondary school students (56\%) have average interest in chemistry. Less of all interested in chemistry 
are Latvian Academy of Music students: only 3\% of them are very interested in chemistry and $7 \%$ are interested in chemistry but $27 \%$ of them are not interested in chemistry and $17 \%$ are not interested in chemistry at all.

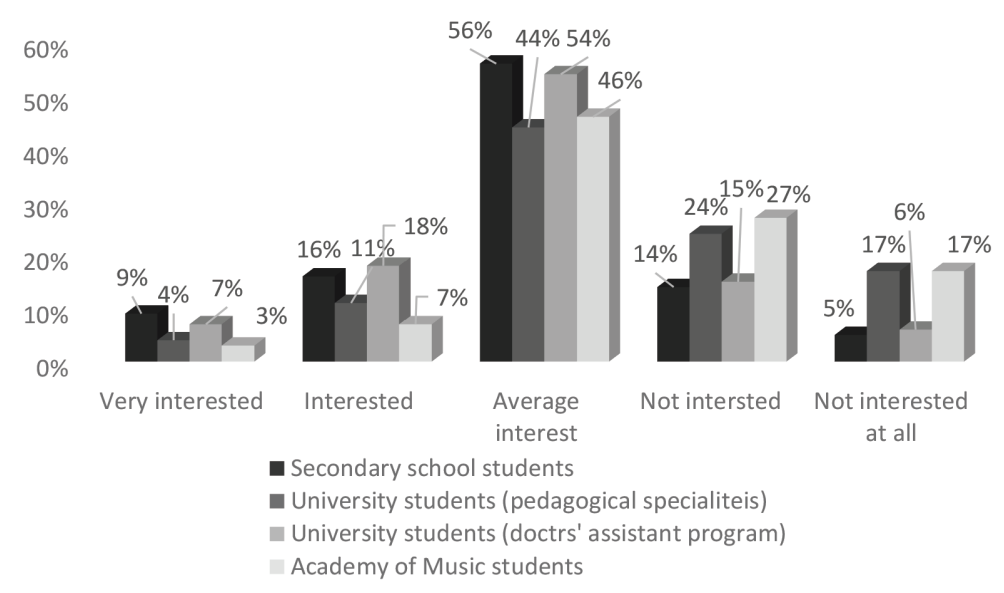

Figure 2. The interest of Latvia students from different specialties in chemistry (in $\%$ from the number of respondents in groups)

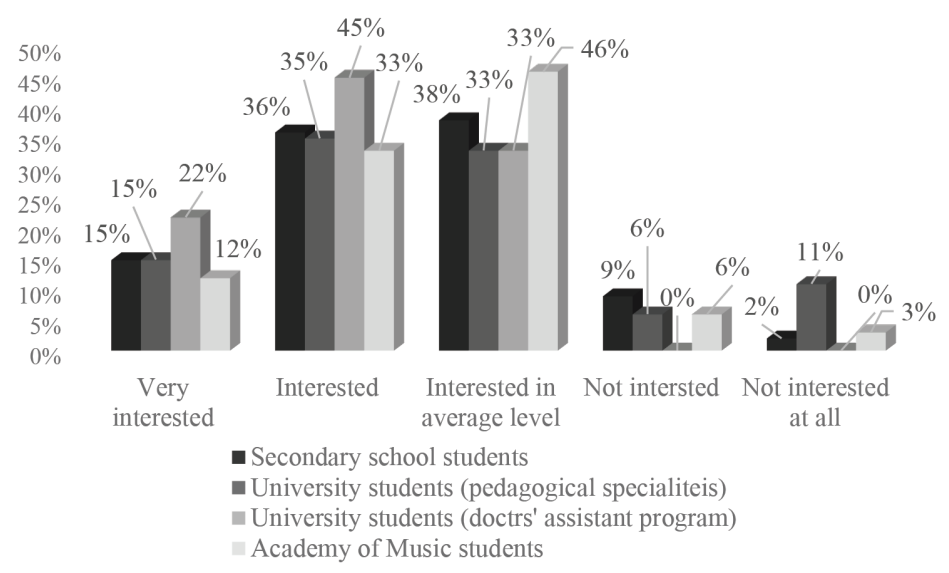

Figure 3. The interest of Latvia students from different specialties in biology (in \% from the number of respondents in groups)

Latvia students' interest in biology is higher than in physics and chemistry (see Fig. 3). Most of all interested in biology are Latvian University doctors' assistant program students: $22 \%$ of them are very interested in biology and 45\% are interested in biology. The other student groups are rather interested in biology: $15 \%$ of secondary school students are very interested in biology and 36\% are interested in biology, $15 \%$ of pedagogical specialties students are very interested in biology and 35\% are 
interested in biology. 12\% of Latvian Academy of Music students are very interested in biology and 33\% are interested in biology.

Results of the survey about students' interest in different science subject topics are displayed in Table 1 and Table 2. From topics connected with physics secondary school students are more interested in such topics as the structure of the Universe (27\% of students are very interested and $46 \%$ of students are interested), electricity and magnetism (14\% of students are very interested and $22 \%$ of students are interested) and radioactivity (9\% of students are very interested and $36 \%$ of students are interested) (see Table 1). Secondary school students are less interested in thermodynamics (21\% of secondary school students are not interested at all) and particle physics (17\% of secondary school students are not interested at all).

Table 1. Latvia secondary school students and University of Latvia pedagogical specialties students interest in different science subject topics (in \% from the number of respondents in groups)

\begin{tabular}{|c|c|c|c|c|c|c|c|c|c|c|}
\hline \multirow[t]{2}{*}{ Topics } & \multicolumn{5}{|c|}{$\begin{array}{l}\text { Secondary school } \\
\text { students }\end{array}$} & \multicolumn{5}{|c|}{$\begin{array}{c}\text { University students } \\
\text { (pedagogical } \\
\text { specialities) }\end{array}$} \\
\hline & 1 & 2 & 3 & 4 & 5 & 1 & 2 & 3 & 4 & 5 \\
\hline Mechanics & 6 & 17 & 55 & 19 & 3 & 11 & 17 & 34 & 19 & 19 \\
\hline Thermodynamics & 2 & 7 & 52 & 18 & 21 & 4 & 11 & 31 & 29 & 25 \\
\hline Electricity and magnetism & 14 & 22 & 52 & 9 & 3 & 6 & 19 & 29 & 23 & 23 \\
\hline Waves and quantum physics & 9 & 17 & 46 & 19 & 9 & 4 & 13 & 35 & 29 & 19 \\
\hline Radioactivity & 9 & 36 & 32 & 18 & 5 & 7 & 15 & 25 & 39 & 14 \\
\hline Particle physics & 6 & 11 & 37 & 31 & 17 & 2 & 6 & 31 & 42 & 19 \\
\hline The structure of the Universe & 27 & 46 & 18 & 9 & 0 & 13 & 29 & 34 & 12 & 12 \\
\hline Properties of substances & 9 & 17 & 46 & 11 & 17 & 7 & 13 & 33 & 31 & 16 \\
\hline Types of chemical reactions & 4 & 33 & 43 & 9 & 11 & 6 & 19 & 25 & 27 & 23 \\
\hline Electrolytic dissociation theory & 6 & 24 & 32 & 19 & 19 & 4 & 11 & 21 & 41 & 23 \\
\hline Electrolysis & 5 & 9 & 52 & 17 & 17 & 4 & 11 & 23 & 39 & 23 \\
\hline Spirits, carboxylic acids and amino acids & 9 & 9 & 46 & 27 & 9 & 2 & 8 & 25 & 40 & 25 \\
\hline Carbohydrates, fats and oils & 9 & 21 & 34 & 27 & 9 & 2 & 19 & 31 & 27 & 21 \\
\hline Construction and diversity of plants & 18 & 37 & 27 & 16 & 2 & 11 & 39 & 32 & 9 & 9 \\
\hline Construction and diversity of animals & 25 & 37 & 27 & 9 & 2 & 17 & 38 & 31 & 8 & 6 \\
\hline Human organism & 27 & 40 & 29 & 4 & 0 & 36 & 25 & 29 & 4 & 6 \\
\hline Human health & 29 & 49 & 18 & 4 & 0 & 52 & 27 & 17 & 2 & 2 \\
\hline Origin and evolution of life & 32 & 52 & 9 & 7 & 0 & 25 & 29 & 36 & 6 & 4 \\
\hline Cell structure & 4 & 17 & 52 & 25 & 2 & 13 & 21 & 45 & 12 & 9 \\
\hline Diversity of living organisms & 9 & 48 & 21 & 18 & 4 & 19 & 31 & 39 & 5 & 6 \\
\hline Genetics and gene engineering & 37 & 37 & 17 & 9 & 0 & 44 & 31 & 21 & 2 & 2 \\
\hline Ecology & 9 & 21 & 52 & 18 & 0 & 15 & 33 & 37 & 6 & 9 \\
\hline
\end{tabular}

Note: 1 - very interested; 2 - interested; 3 - average interest; 4 - not interested; 5 - not interested at all 
University pedagogical specialties students are more interested in the structure of the Universe $(13 \%$ of students are very interested and $29 \%$ of students are interested) and mechanics (11\% of students are very interested and $17 \%$ of students are interested). University doctors' assistant program students are interested in the structure of the Universe ( $9 \%$ of students are very interested and $15 \%$ of students are interested) (see Table 2) but they are not interested in waves and quantum physics, thermodynamics and radioactivity. The majority of Latvian Academy of Music students are not interested in topics of physics, except the structure of the Universe.

From chemistry subject topics secondary school students are more interested in types of chemical reactions (4\% of students are very interested and $33 \%$ of students are interested) and electrolytic dissociation theory (6\% of students are very interested and $24 \%$ of students are interested). The majority of the University of Latvia pedagogical specialties students are not interested in different topics of chemistry such as spirits, carboxylic acids and amino acids (25\% of the University of Latvia pedagogical specialties students are not interested at all), types of chemical reactions, electrolytic dissociation theory, electrolysis $(23 \%$ of the University of Latvia pedagogical specialties students are not interested at all). Some of the University of Latvia Riga Medical College doctors' assistant program students are interested in such topics of chemistry as properties of substances and types of chemical reactions (11\% of students are very interested in these themes).

The majority of Latvian Academy of Music students have average interest or they are not interested in different topics connected with chemistry, such as electrolysis (24\% of Latvian Academy of Music students are not interested at all) and electrolytic dissociation theory (22\% of Latvian Academy of Music students are not interested at all).

All student groups are more interested in biology subject topics in comparison with topics of physics and chemistry. Students are especially interested in such topics as: genetics and gene engineering (37\% of secondary school students, $44 \%$ of University pedagogical specialties students, $33 \%$ of University doctors' assistant program students and $15 \%$ of Latvian Academy of Music students are very interested in these themes); human organism (27\% of secondary school students, $36 \%$ of University pedagogical specialties students, $27 \%$ of University doctors' assistant program students and $22 \%$ of Latvian Academy of Music students are very interested in these themes); human health (29\% of secondary school students, $52 \%$ of University pedagogical specialties students, $34 \%$ of University doctors' assistant program students and $27 \%$ of Academy of Music students are very interested in these themes) and origin and evolution 
of life (32\% of secondary school students, 25\% of University pedagogical specialties students, $18 \%$ of University doctors' assistant program students and 14\% of Latvian Academy of Music students are very interested in these themes).

Table 2. University of Latvia doctors' assistant program students and Latvian Academy of Music students' interest in different science subject topics (in \% from the number of respondents in groups)

\begin{tabular}{|c|c|c|c|c|c|c|c|c|c|c|}
\hline \multirow[t]{2}{*}{ Topics } & \multicolumn{5}{|c|}{$\begin{array}{c}\text { University students } \\
\text { (doctors' assistant } \\
\text { program) }\end{array}$} & \multicolumn{5}{|c|}{$\begin{array}{l}\text { Latvian Academy of } \\
\text { Music students }\end{array}$} \\
\hline & 1 & 2 & 3 & 4 & 5 & 1 & 2 & 3 & 4 & 5 \\
\hline Mechanics & 5 & 14 & 46 & 22 & 13 & 2 & 2 & 43 & 37 & 16 \\
\hline Thermodynamics & 3 & 11 & 45 & 24 & 17 & 0 & 2 & 38 & 41 & 19 \\
\hline Electricity and magnetism & 5 & 11 & 56 & 15 & 13 & 3 & 6 & 53 & 27 & 11 \\
\hline Waves and quantum physics & 2 & 9 & 44 & 24 & 21 & 2 & 3 & 37 & 37 & 21 \\
\hline Radioactivity & 7 & 11 & 23 & 38 & 21 & 2 & 9 & 37 & 33 & 19 \\
\hline Particle physics & 5 & 17 & 34 & 22 & 22 & 0 & 4 & 41 & 31 & 24 \\
\hline The structure of the Universe & 9 & 15 & 42 & 22 & 12 & 11 & 6 & 56 & 27 & 0 \\
\hline Properties of substances & 11 & 17 & 44 & 16 & 12 & 4 & 6 & 44 & 37 & 9 \\
\hline Types of chemical reactions & 11 & 18 & 39 & 18 & 14 & 5 & 9 & 46 & 23 & 17 \\
\hline Electrolytic dissociation theory & 2 & 11 & 33 & 33 & 21 & 2 & 5 & 41 & 30 & 22 \\
\hline Electrolysis & 3 & 21 & 54 & 11 & 11 & 3 & 6 & 40 & 27 & 24 \\
\hline Spirits, carboxylic acids and amino acids & 7 & 11 & 33 & 28 & 21 & 7 & 9 & 43 & 26 & 15 \\
\hline Carbohydrates, fats and oils & 9 & 22 & 22 & 28 & 19 & 6 & 11 & 45 & 25 & 13 \\
\hline Construction and diversity of plants & 11 & 21 & 33 & 22 & 13 & 11 & 17 & 48 & 20 & 4 \\
\hline Construction and diversity of animals & 14 & 22 & 34 & 19 & 11 & 17 & 21 & 47 & 11 & 4 \\
\hline Human organism & 27 & 34 & 39 & 0 & 0 & 22 & 33 & 44 & 9 & 2 \\
\hline Human health & 34 & 37 & 29 & 0 & 0 & 27 & 41 & 27 & 5 & 0 \\
\hline Origin and evolution of life & 18 & 22 & 49 & 11 & 0 & 14 & 33 & 45 & 4 & 4 \\
\hline Cell structure & 11 & 36 & 42 & 11 & 0 & 12 & 15 & 55 & 14 & 4 \\
\hline Diversity of living organisms & 17 & 38 & 41 & 2 & 2 & 17 & 19 & 53 & 9 & 2 \\
\hline Genetics and gene engineering & 33 & 56 & 11 & 0 & 0 & 15 & 26 & 48 & 7 & 4 \\
\hline Ecology & 33 & 45 & 22 & 0 & 0 & 17 & 24 & 52 & 5 & 2 \\
\hline
\end{tabular}

Note: 1 - very interested; 2 - interested; 3 - average interest; 4 - not interested; 5 - not interested at all

Students are also interested in topics connected with ecology, for example, $33 \%$ of the University of Latvia Riga Medical College doctors' assistant program students are very interested and $45 \%$ of them are interested in these topics. The majority of students have average interest in such topics as construction and diversity of plants. 
The results of current research correlate with the results of other studies, which suggest that students usually have the higher interest in biology but the interest in chemistry and physics is lower (Lamanauskas et al., 2004). An important task for teachers is to find out a way, how to raise students' interest in science subjects. The methods which raise students' interest in science and help gaining understanding about the nature of the science are experiment demonstrations and laboratory works (Cedere et al., 2016) and group works and discussions (Porozovs et al., 2015), and teachers are advised to use these methods during lessons.

\section{Conclusions}

1. The interest of Latvia students from different specialities in physics and chemistry is rather low: many students have average interest in these subjects. Latvia students' interest in biology is higher than in physics and chemistry.

2. From topics connected with physics students are most of all interested in the structure of the Universe. Secondary school students are also interested in electricity and magnetism and radioactivity, University of Latvia pedagogical specialties students in mechanics but University of Latvia Riga Medical College doctors' assistant program students in radioactivity. The majority of Latvian Academy of Music students are not interested in topics of physics.

3. From chemistry subject topics secondary school students are more interested in types of chemical reactions, electrolytic dissociation theory and carbohydrates, fats and oils but University of Latvia Riga Medical College doctors' assistant program students in types of chemical reactions and carbohydrates, fats and oils. The majority of the University of Latvia pedagogical specialities students and Latvian Academy of Music students are not interested in different topics of chemistry.

4. The most interesting topics of biology for all student groups are genetics and gene engineering, the human organism, human health, origin and evolution of life and ecology. Most of all interested in biology from surveyed student groups are the University of Latvia Riga Medical College doctors' assistant program students.

\section{References}

Birzina, R., \& Cedere, D. (2017). The first year students' perceptions of higher studies: a case of University of Latvia. In V. Dislere (Eds.), Rural environment, education, personality (pp. 40-49). Jelgava: Latvia University of Agriculture.

Bottia, M. C., Stearns, E., Mickelson R. A., \& Moller, S. (2017). Boosting the numbers of STEM majors? The role of high schools with a STEM program. Science Education, 
102, 85-107. DOI:10.1002/sce.21318 Retrieved from https://onlinelibrary.wiley.com/ doi/epdf/10.1002/sce.21318.

Cedere, D., Gedrovics, J., Bilek, M., \& Mozeika, D. (2014). Changes of 15 years old students' interest in science in Latvia: 2003-2013. In M. Bilek (Eds.), Science and technology education for the 21 ${ }^{\text {st }}$ century, (pp. 103-112). Hradec Králové: Gaudeamus.

Cēdere, D., Jurgena, I., Helmane, I., Tiltiņa-Kapele, I., \& Praulīte, G. (2015). Cognitive Interest: Problems and Solutions in the Acquisition of Science and Mathematics in Schools of Latvia. Journal of Baltic Science Education, 14(4), 424-434. Retrieved from http:// www.scientiasocialis.lt/jbse/files/pdf/vol14/424-434.Cedere_JBSE_Vol.14_No.4.pdf.

Cēdere, D., Jurgena, I., \& Praulīte, G. (2016). Possibilities of Promoting Students' Cognitive Interest in Science Subjects. Engineering for Rural Development - International Scientific Conference, 511-516. Retrieved from http://www.tf.llu.lv/conference/ proceedings2016/Papers/N094.pdf

Cēdere, D, Jurgena, I., \& Targamadze, V. (2018). Interest of Latvian and Lithuanian Students in Science and Mathematics. Journal of Baltic Science Education, 17(1), 31-42.

Čipková, E., Karolčík, Š., Dudová, N., \& Nagyová, S. (2018). What is the students' interest in biology after the biology curriculum modification? Curriculum Journal. 29(3), 370-386. DOI: 10.1080/09585176.2017.1406811.

Jansen, M., Schroeders, U., Lüdtke, O., \& Marsh. H. V. (2019). The dimensional structure of students' self-concept and interest in science depends on course composition. Learning and Instruction, 60, 20-28.

Lamanauskas, V., Gedrovics, J., \& Raipulis, J. (2004). Senior Pupils' Views and Approach to Natural Science Education in Lithuania and Latvia. Journal of Baltic Science Education, 3(1), 13-23.

Luce, M. R., \& His, S. (2015). Science-Relevant Curiosity Expression and Interest in Science: An Exploratory Study. Science Education, 99(1), 70-97.

Michael, J. B., Ling, L., Kuay-Keng, Y., \& Huann-shyang, L. (2017). A Science for Citizenship Model: Assessing the Effects of Benefits, Risks, and Trust for Predicting Students' Interest in and Understanding of Science-Related Content. Research in Science Education, 47(5), 965-988.

Pečiuliauskienè, P. (2012). Educational Factors Affecting Positive Attitude of Pupils Towards Science Subjects. Pedagogy Studies / Pedagogika. 2012, 105, 32-39.

Porozovs, J., Liepniece, L., \& Voita, D. (2015). Evaluation of the Teaching Methods Used in Secondary School Biology Lessons. Signum Temporis, 7(1), 60-66. DOI 10.1515/sigtem-2016-0009 Retrieved from https://www.researchgate.net/publication/ 332577437_Evaluation_of_the_Teaching_Methods_Used_in_Secondary_School_Biology_ Lessons.

Safari, Y., Navazeshkhah, F., Azizi, M., Ziaei, M., \& Sharafi, K. (2015). The Effective Factors on the Postgraduate Students' Interest and Participation in Performing Research Activities - Case Study: Kermanshah University of Medical Science. Future of Medical Education Journal, 5(2), 3-9. DOI: 10.22038/FMEJ.2015.4454 Retrieved from http:// fmej.mums.ac.ir/article_4454.html.

Sadler, P. M., Sonnert, G., Hazari, Z. \& Tai, R. (2014). The Role of Advanced High School Coursework in Increasing STEM Career Interest. ScienceEducator, 23(1), 1-13. Retrieved from https://www.nsela.org/assets/The\%20Role\%20of\%20Advanced\%20High\%20School\% 20Coursework\%20in\%20Increasing\%20STEM\%20Career\%20Interest.pdf. 
Salonen, A., Kärkkäinen, S., \& Keinonen, T. (2018). Career-Related Instruction Promoting Students' Career Awareness and Interest towards Science Learning. Chemistry Education Research and Practice, 19(2), 474-483. DOI: 10.1039/C7RP00221A.

Taly, A., Nitti, F., Baaden, M. \& Pasquali, S. (2019). Molecular modelling as the spark for ac-tive learning approaches for interdisciplinary biology teaching. Interface Focus, 9 (3): 20180065. DOI: https://doi.org/10.1098/rsfs.2018.0065 Retrieved from http:// dx.doi.org/10.1098/rsfs.2018.0065.

Uitto, A. (2014). Interest, Attitudes and Self-Efficacy Beliefs Explaining Upper-Secondary School Students' Orientation Towards Biology-Related Careers. International Journal of Science and Mathematics Education, 12 (6), 1425-1444. 